Volume 4 No 1 September 2018 p-ISSN : 2460-8750 e-ISSN : 2615-1731

\title{
KOMITMEN ORGANISASI DAN PRODUKTIVITAS KERJA DITINJAU DARI GAYA KEPEMIMPINAN INTRINSIK: KAJIAN SPIRITUALITAS DAN AGAMA DI TEMPAT KERJA
}

\author{
Sitti Syawaliyah Gismin ${ }^{1}$ Ahmad Yasser Mansyur ${ }^{2}$ \\ ${ }^{1}$ Universitas Bosowa Makassar ${ }^{2}$ Universitas Negeri Makassar \\ E-mail: stsyawaliyah@gmail.com ${ }^{1}$ ahmadyasser_mansyur@yahoo.com ${ }^{2}$
}

C 2018 -JPT Fakultas Psikologi Universitas Negeri Makassar. Ini adalah artikel dengan akses terbuka dibawah licenci CC BY-NC-4.0 (https://creativecommons.org/licenses/by-nc/4.0/ ).

\begin{abstract}
Abstrack. This study aims to examine the effect of three leadership styles namely prophetic leadership, spiritual leadership and transformational leadership on organizational commitment and work productivity in the organization. A total of 216 respondents from three organizations (business, public and non-profit) based on Islam in the Makassar-Indonesia region were involved in this study. Five measuring tools were used to gather information about the variables studied, namely the Organizational Commitment Questionnaire, Productivity, the SLT Survey Questions, the Multifactor Leadership Questionnaire and L-Prophetic. Parametric inferential statistics in the form of multiple regression analysis and one-way ANOVA are used to reveal the results of each of the variables studied. The results of the study show that there are joint effects of three leadership styles on organizational commitment and work productivity. Of the three leadership styles, prophetic leadership style and dominant spiritual leadership influence organizational commitment and work productivity. In addition, the three leadership styles have the same dominance (existence) in nonprofit organizations. The results of this study enriched the concept of sharia-based prophetic leadership style that was useful for the development of SRW studies, Islamic Psychology and supported the spirit of Indigenous Psychology.
\end{abstract}

Keywords: Intrinsic leadership, organizational commitment, work productivity

Abstrak. Kajian ini bertujuan untuk menguji pengaruh tiga gaya kepemimpinan yaitu kepemimpinan profetik, kepemimpinan spiritual dan kepemimpinan transformasional terhadap komitmen organisasi dan produktivitas kerja dalam organisasi. Sebanyak 216 responden dari tiga organisasi (bisnis, publik dan nonprofit) berasas Islam di wilayah Makassar-Indonesia dilibatkan dalam kajian ini. Lima alat ukur digunakan untuk mengumpulkan informasi mengenai variabel yang dikaji, yaitu Organizational Commitment Questionnaire, Productivity, SLT Survey Questions, Multifactor Leadership Questionnaire dan L-Prophetic. Statistik inferensif parametrik berupa analisis regresi ganda dan Anava satu jalur digunakan untuk mengungkap hasil dari masing-masing variabel yang diteliti. Hasil kajian menunjukkan terdapat pengaruh bersama tiga gaya kepemimpinan terhadap komitmen organisasi dan produktivitas kerja. Dari ketiga gaya kepemimpinan itu, gaya kepemimpinan profetik dan kepemimpinan spiritual dominan mempengaruhi komitmen organisasi dan produktivitas kerja. Selain itu, ketiga gaya kepemimpinan memiliki kesamaan dominasi (keberadaan) pada organisasi nonprofit. Hasil kajian ini memperkaya konsep gaya kepemimpinan profetik berasas syariah yang bermanfaat bagi pengembangan kajian SRW, Psikologi Islami dan mendukung semangat Indigenous Psychology.

Kata Kunci: kepemimpinan intrinsik, komitmen organisasi, produktivitas kerja 


\section{PENDAHULUAN}

Terdapat beberapa organisasi di bumi ini yang mengalami kehancuran dan organisasi yang dapat bertahan dalam perubahan lingkungannya. Hal itu sesuai dengan Al-Qur`an surah al-An`aam ayat 6 yang terjemahannya berbunyi:

"Apakah mereka tidak memperhatikan berapa banyak generasi yang telah Kami binasakan sebelum mereka, padahal (generasi itu) telah Kami teguhkan kedudukan mereka di muka bumi, yaitu keteguhan yang belum pernah Kami berikan kepadamu, dan Kami curahkan hujan yang lebat atas mereka dan Kami jadikan sungaisungai mengalir di bawah mereka, kemudian Kami binasakan mereka karena dosa mereka sendiri, dan Kami ciptakan sesudah mereka generasi yang lain (QS. Al-An`aam: 6”).

Ayat tersebut berisi pelajaran agar manusia dapat kembali pada jalan kebenaran (sesuai hukum syariah) dan agar dapat menyesuaikan diri terhadap perubahan lingkungan yang terjadi. Nilainilai hukum syariah itu mengatur kehidupan ibadah dan hal-hal yang bersifat mu`amalah (kehidupan sosial kemasyarakatan) seperti halal-haram, mengatur perilaku yang tidak boleh dilakukan yaitu riba, judi, dholim (aniaya), gharar (penipuan), barang haram, maksiat, risywah (suap) (Luwu, 2011). Era moderen pada masa ini ditandai dengan perubahan lingkungan yang cepat dan kemajuan teknologi informasi. Di Indonesia, terdapat fenomena organisasi yang bertahan dan dapat merespon baik terhadap perubahan lingkungan organisasi, diantaranya organisasi bisnis dan nonfrofit. Pada tahun 2007 banyak organisasi mengalami gulungtikar. Menurut Agustianto (2008), dampak dari krisis ekonomi itu sekitar $80 \%$ perusahaan, unit usaha dan bank konvensional mengalami negative spread sehingga berakibat pada proses likuidasi atau dimerger dengan bank lain. Seperti dibentuknya Bank Mandiri yang dulunya dari bank Exim, Bapindo, Bumi Daya dan Dagang Negara. Selanjutnya menurut Agustianto, kondisi itu berbeda dengan perbankan yang dikelola secara syariah, dimana perbankan syariah tidak mengalami likuidasi.

Hingga kini lembaga-lembaga perbankan syariah ataupun lembaga keuangan nonbank di Indonesia menunjukkan perkembangan yang sangat pesat. Berkenaan dengan itu Haliding (2011) menyatakan pencapaian perbankan syariah terus mengalami peningkatan dalam jumlah bank. Selain itu, menurut Luwu (2011), sampai tahun 2010 aset perbankan syariah mencapai 100 trilyun dengan 6 juta nasabah serta 20 ribu tenaga kerja. Kemudian pada tahun 2011 perkembangan perbankan syariah biperkirakan tumbuh sampai 50\% sehingga perbankan syariah menjadi industri besar.

Menurut Nashir (2007) sebagai gerakan Islam, Muhammadiyah merupakan suatu gerakan agama (religious movements), yang di dalamnya terkandung sistem keyakinan (belief system), pengetahuan (knowledge), organisasi (organizations), dan praktik-praktik aktivitas (practices activity) dan kepemimpinan yang mengarah pada tujuan (goal) yang dicitacitakan. Sedangkan organisasi yang dikelola secara syariah (sesuai dengan nilai-nilai agama Islam) dapat terus berkembang di tengah dinamika perubahan lingkungan organisasi. Fakta itu sesuai dengan pernyataan Luwu (2011), bahwa 
pengalaman dari robohnya struktur pondasi ekonomi Indoensia di tahun 1997 menyadarkan bangsa Indonesia bahwa ekonomi kapitalis sangat rentan dengan masalah. Terlepas dari manajemen organisasi dan sistem syariah, ada dua alasan dasar bertahannya organisasi yang dikelola secara syariah dalam perspektif kepemimpinan, yaitu:

a. Efektivitas kepemimpinan SRW. Kepemimpinan efektif sangat diperlukan dalam kehidupan moderen dan arus global saat ini dan di masa depan yang ditandai dengan kehidupan yang serba teknikal dan profesional. Oleh itu, Sanders, Hopkins dan Geroy (Scott, 2008) menyarankan agar masa ini dibutuhkan kepemimpinan transendental (spiritual) yang dapat mewujudkan efektivitas kepemimpinan. Hasan (2005) menganjurkan saran agar pemimpin masa depan harus menonjol pada bidang lunak, yang kurang dapat diukur dengan fisik dan matematik, seperti kepribadian, nilai yang diyakini secara pribadi (spiritual). Dengan adanya tantangan dan perubahan lingkungan di masa depan, mengharuskan para pemimpin untuk mampu mengidentifikasi, memperkuat dan hidup sebagai model dari nilai-nilai inti (rute models of key core value) dari spiritual dan agama.

b. Adanya komitmen internal pekerja. Menurut Rokhman (2002), pemimpin mempunyai peran strategik dalam proses pemberdayaan pekerja (empowerment). Proses itu adalah pimpinan menciptakan kondisi saling percaya dengan pekerja, melibatkan pekerja dalam proses kebijakan dan pemberian tanggungjawab terhadap bawahan. Hal itu akan membentuk kondisi intrinsik pada pekerja sehingga mampu mencapai produktivitas dan kerja yang optimal. Istilah intrinsik di sini oleh Rokhman (2002) disebut sebagai komitmen internal. Munculnya sikap dan perilaku komitmen internal bawahan sangat ditentukan oleh sosok pemimpin.

\section{Kepemimpinanm berdasar spiritualitas} dan teologis. Di dunia Barat, konsep kepemipimpinan dilakukan dengan beberapa pendekatan seperti pendekatan sifat (traits), perilaku (behavioral), peran (roles), situasional (situational) dan relasional (relational) (AlSarhi et al., 2014). Pada saat ini berkembang model kepemimpinan yang berdasarkan perkembangan teori motivasi, sebagaimana yang diungkap oleh Fry (2003). Menurutnya, terdapat dua jenis dasar motivasi, yaitu motivasi ekstrinsik dan motivasi intrinsik. Gaya kepemimpinan yang termasuk dalam motivasi intrinsik diantaranya kepemimpinan kepemimpinan spiritual dan kepemimpinan transformasional. Selain gaya kepemipinan tersebut, yang relatif baru adalah gaya kepemimpinan profetik berdasar teologi dan moral. Di dunia barat, konsep profetik didasari dari konsep agama Kristen. Seperti Walsh (2014) yang mengkaji cara mengatasi masalah trauma dengan pendekatan yang berdasarkan pada praktek pelayanan pastoral kenabian di Amerika. Menurut Budiharto dan Himam (2006), kepemimpinan profetik juga telah dikaji secara konseptual berdasarkan pendekatan iman Kristiani. Di Indonesia, istilah profetik pertama kali dipopulerkan oleh Kuntowijoyo pada tahun 2006. Inspirasi teologis tesebut bersumber dari Al-Qur`an surat Ali Imran ayat 110. Seperti pada tahun 2006, Sus Budiharto dan Fathul Himam meneliti konstruk teoritis dan pengukuran kepemimpinan profetik. 
Dimensi kepemimpinan profetik terdiri dari empat aspek, yaitu sidiq, amanah, tabligh, dan fathonah. Selain itu, pengembangan konsep profetik juga dilakukan Mansyur (2013). Konsep itu dinamakan personal prophetic leadership (Perpec-L). Perpec-L merupakan gaya kepemimpinan profetik yang bersifat pribadi (individual) yang tidak hanya dimiliki oleh para nabi dan pemimpin saja, namun juga dimiliki oleh setiap pribadi yang dengan sadar dan konsisten menjalankan ajaran agamanya, sehingga terwujud kesadaran otonomi dan intrinsik individu dalam melakukan aktivitasnya. Pada tahun 2008, Arifiyanto dan Budiharto meneliti kepemimpinan profetik yang dulu pernah dilakukan oleh Nabi Muhammad SAW, dan para sahabat r.a. dapat berpengaruh dan mempunyai hubungan positif dengan kepuasan kerja. Penelitian aplikatif terbaru oleh Perbawa dan Sarasi pada tahun 2014 yang meneliti penerapan model kepemimpinan profetik dalam mengembangkan program Pembinaan Sumber Daya Manusia Strategis di lembaga pendidikan.

Kepemimpinan Spiritual. Menurut Fry (2003\&2005) merupakan kumpulan nilai-nilai, sikap, dan perilaku yang diperlukan untuk memotivasi diri sendiri maupun orang lain secara intrinsik, sehingga masing-masing memiliki perasaan survival yang bersifat spiritual melalui keanggotaan dan keterpanggilan. Kepemimpinan spiritual mempunyai tiga unsur, yaitu: penciptaan visi, cinta altruistik, dan iman/harapan.

Kepemimpinan profetik. Menurut Budiharto dan Himam (2005) adalah kemampuan mengendalikan diri dan mempengaruhi orang lain dengan tulus untuk mencapai tujuan bersama sebagaimana dilakukan oleh para nabi.
Dalam kesempatan ini, peneliti hanya mengkhususkan pada kepemimpinan nabi Muhammad SAW. Banyak hal yang menyebabkan mengapa kepemimpinan prophetik ditujukan pada nabi Muhammad SAW. Para pakar akademik Barat secara ilmiah telah mengakui kelebihan nabi Muhammad SAW dalam hal kepemimpinan. Misalnya Campbell (2008) menyatakan Muhammad berasal dari pemimpin Islam yang berhasil dan efektif melakukan transformasi hidup dalam institusi sosial. Selain itu Hart pada tahun 1978 mengarang buku "Seratus Tokoh yang Paling Berpengaruh dalam Sejarah". Ia menempatkan Muhammad SAW sebagai tokoh urutan pertama dalam seratus tokoh dunia.Pengertian kepemimpinan profetik dinyatakan oleh Mansyur (2013) adalah nilai-nilai kepemimpinan yang bersumber dari nabi Muhammad SAW dan Al-Qur`an untuk mengajak seseorang mencapai tujuan organisasi.

Kepemimpinan transformasional merupakan model yang relatif baru (the new leadership) dalam studi-studi kepemimpinan kontemporer dan konvensional. Howard dan Victoria (2007) serta Jandaghi et al. (2008) mengemukakan bahwa kepemimpinan transformasional mempunyai empat dimensi yang disebutnya sebagai "the Four I's". Dalam kajian ini, kepemimpinan transformasional diukur dengan Multifactor Leadership Questionnaire (MLQ-2) yang dicipta oleh Bass dan Avolio (1994). Komitmen organisasi. Mowday et al. (1982) mendefinisikan komitmen organisasi memiliki arti lebih dari sekedar loyalitas yang pasif, tetapi melibatkan hubungan aktif dan keinginan pekerja untuk memberikan kontribusi yang berarti pada organisasinya. Menurutnya, komitmen organisasi terbangun bila masing-masing individu mengembangkan tiga sikap yang 
saling berhubungan terhadap organisasi yaitu: 1. Identification yaitu pemahaman atau penghayatan dari tujuan organisasi. 2 . Involment yaitu perasaan terlibat dalam suatu pekerjaan atau perasaan bahwa pekerjaannya adalah menyenangkan. 3 . Loyality yaitu perasaan bahwa organisasi adalah tempat bekerja dan tempat tinggal.

Produktivitas kerja. Menurut Hasan (2004), produktivitas kerja menyangkut apa yang dapat dihasilkan oleh manusia, dalam hal jumlah yang lebih banyak dan kualitas yang lebih baik. Secara operasi, produktivitas kerja dalam kajian ini adalah peningkatan kualitas hasil kerja oleh anggota organisasi berdasarkan efesiensi hasil produk, manfaat dan keuntungan. Produktivitas kerja itu diukur dengan alat ukuran produktivitas kerja yang dicipta oleh Fry (2003).

Setelah memahami latarbelakang masalah dan definisi masing-masing variabel penelitian, maka selanjutnya secara singkat diurai literatur hasil penelitian guna menyusun model penelitian (sebagaimana yang terdapat pada gambar 1) dan membangun hipotesis.

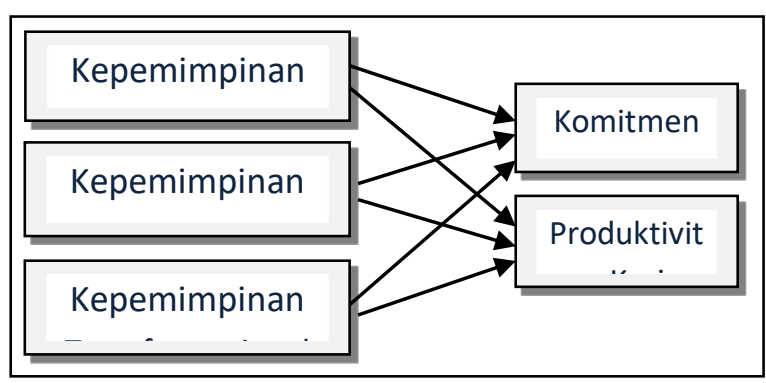

Gambar 1. Model Penelitian

Kajian ilmiah mengenai pengaruh kepemimpinan profetik terhadap komitmen organisasi dan produktivitas kerja belum banyak dilakukan. Hanya ada satu hasil penelitian yang berkaitan dengan produktivitas kerja, yaitu penelitian yang dilakukan oleh Dewi (2013) pada karyawan
PLTU di Makassar. Hasil penelitian itu mendapatkan adanya pengaruh signifikan gaya kepemipinan profetik terhadap produktivitas kerja karyawan. Kajian yang mendukung lainnya, diantaranya penelitian yang dilakukan oleh Arifiyanto dan Budiharto (2008) menunjukkan kepemimpinan profetik (Nabi Muhammad SAW) berpengaruh dan mempunyai hubungan positif dengan kepuasan kerja karyawan dan guru yang bekerja di sekolah Islami Yogyakarta. Selain itu, Perbawa dan Sarasi (2014) menyatakan model kepemimpinan profetik dapat mengembangkan program Pembinaan Sumber Daya Manusia Strategis di lembaga Nurul Fikri Indonesia.

Kajian konsep kepemimpinan spiritual telah dilakukan oleh Fry (2003, 2005). Ia menyatakan kepemimpinan spiritual bersifat motivasi intrinsik, dimana seseorang memiliki perasaan keanggotaan dan keterpanggilan, sehingga pekerja dapat menimbulkan komitmen organisasi dan produktivitas kerja dalam organisasinya. Hal yang sama itu sesuai dengan pendapat beberapa tokoh dan rujukan yang ada, seperti Fry dan Whittington (t.th), Giacalone et al. (2005), Fry dan Whittington (2005) serta Fry dan Slocum (2008). Dari kajian itu didapati bahwa pengembangan kepemimpinan spiritual di tempat kerja berpengaruh positif terhadap kelangsungan organisasi, berupa budaya organisasi, komitmen organisasi, produktivitas kerja, kepuasan kerja, dan dapat mengurangi ketidakhadiran pekerja. Kajian lapangan pada organisasi bisnis telah dilakukan oleh Fry dan Matherly pada tahun 2006. Sebanyak 347 pekerja produk elektrik dilibatkan dalam kajian itu dengan hasil kepemimpinan spiritual berpengaruh terhadap komitmen organisasi 
(80\%), produktivitas $(56 \%)$ dan pertumbuhan penjualan (13\%). Kemudian Matherly et al. (2005) telah melakukan kajian dengan berusaha menerapkan konsep kepemimpinan spiritual dalam organisasi Tomasso Corporation'S (merupakan organisasi ekonomi dan kemanusiaan) di Canada. Hasil kajian menunjukkan terdapat pengaruh kepemimpinan spiritual terhadap komitmen anggota organisasi, produktivitas, kesejahteraan psikologis dan kepuasan pelanggan. Selain itu Chen (2012) mengadakan kajian perbandingan dampak dari kepemimpinan spiritual terhadap perilaku organisasi (organizational citizenship behavior) pada organisasi pembiayaan (finance) dan industri ritel. Hasil penelitian menunjukkan bahwa nilainilai, sikap, dan perilaku pemimpin spiritual memiliki efek yang positif terahadap keterpanggilan dan keanggotaan karyawan, dan lebih memudahkan karyawan untuk melakukan perilaku warga organisasi yang sangat baik, termasuk altruisme terhadap rekan-rekan dan kesadaran tanggung jawab terhadap organisasi.

Kajian dalam organisasi publik antara lain dilakukan oleh Malone dan Fry (2003). Kajian eksperimen dengan dengan melibatkan 229 pekerja dari dua sekolah di Texas untuk menguji model kepemimpinan spiritual terhadap survival spiritual pekerja, komitmen organisasi dan produktivitas. Hasil kajian menunjukkan gaya kepemimpinan spiritual mempunyai pengaruh terhadap komitmen organisasi dan produktivitas kerja. Penelitian terbaru dalam organisasi bisnis dilakukan oleh Khoshpanjeh et al., pada tahun 2012 yang meneliti peran dimensi kepemimpinan spiritual dalam pemberdayaan karyawan dan efeknya signifikan terhadap produktivitas tenaga kerja di Bank Mellat
Kota Teheran. Selain itu, Sweeney dan Fry (2012) meneliti model kepemimpinan spiritual untuk digunakan mengembangkan karakter di tempat kerja. Pengembangan karakter dapat memperbaiki diri karyawan dan organisasi, serta mempengaruhi komitmen pekerja terhadap organisasi.

Penelitian tentang kepemimpinan transformasional telah dilakukan oleh Spinelli (2006). Ia menyatakan bahwa kepemimpinan transformasional berperanan untuk meningkatkan komitmen organisasi dan produktivitas kerja anggota organisasi. Kajian tentang pengaruh kepemimpinan transformasional terahadap komitmen organisasi telah dilakukan Ross dan Gray pada tahun 2006. Hasil penelitian itu menyatakan kepemimpinan transformasional berperan untuk meningkatkan komitmen guru terhadap nilai-nilai organisasi.

Selain menguji tiga gaya kepemimpinan terhadap komitmen organisasi dan produktivitas kerja, peneltian ini juga akan mengetahui dominasi ketiga gaya kepemimpinan tersebut dalam organisasi bisnis, publik dan nonprofit. Tidak didapatkan konsep teori dan hasil penelitian tentang dominasi kepemimpinan profetik, kepemimpinan spiritual dan kepemimpinan transformasional dalam organisasi bisnis, publik dan nonprofit. Salusu (2000) menyatakan masing-masing organisasi memiliki karakteristik dalam melakukan pelayanan. Organisasi bisnis memberi pelayanan dengan motif mencari untung (materi). Dalam definisi kepemipinan profetik (Budiharto dan Himam, 2005) terdapat usaha yang tulus dari pemimpin dan anggotanya dalam mencapai tujuan organisasi. Usaha itu memiliki kesamaan sebagaimana yang dilakukan oleh para nabi 
berdasarkan perintah Tuhan dan tidak membutuhkan pamrih dari manusia. Sedangkan dalam kepemimpinan spiritual, terdapat unsur cinta altruistik. Ini bermakna dalam menegakkan suatu budaya organisasi dilakukan dengan tanpa pamrih pribadi, dimana para pemimpin dan anggotanya memiliki perhatian, kepedulian, dan penghargaan yang tulus satu sama lain. Berdasar konsep ihlas dan tanpa pamrih itu dan karakter organisasi nonprofit, maka dapat dinyatakan adanya kecenderungan dominasi gaya kepemimpinan profetik dan kepemimpinan spiritual dalam organisasi nonprofit.

Berdasarkan konsep teori dan kajian literatur di atas, maka dapat dibangun hipotesis penelitian sebagai berikut:

1. Terdapat pengaruh tiga gaya kepemimpinan (spiritual, profetik dan transformasional) terhadap komitmen organisasi dan produktivitas kerja.

2. Ketiga gaya kepemimpinan memiliki kesamaan dominasi pada organisasi nonprofit.

\section{METODE}

Penelitian ini dilaksanakan di kota Makassar - Indonesia, dengan melibatkan sebanyak 216 karyawan di tiga jenis organisasi berasas Islam, dengan masingmasing jumlah responden dalam organisasi bisnis (72 orang) profit (73 orang) dan nonprofit (71 orang). Pengambilan sampel penelitian dilakukan dengan teknik random sampling.

Teknik analisis. Statistik inferensif parametrik berupa analisis regresi ganda dan Anova satu jalur digunakan untuk mengungkap hasil dari masing-masing variabel yang diteliti.

\section{HASIL DAN PEMBAHASAN}

Hipotesis pertama diuji menggunakan teknik analisis regresi ganda dengan dua metode, yaitu metode enter dan stepwise. Metode enter digunakan sebagai langkah pertama untuk menguji pengaruh tiga gaya kepemimpinan terhadap komitmen organisasi dan produktivitas kerja. Metode stepwise digunakan untuk menguji variabel yang paling dominan. Adapun hasil kedua metode tersebut dapat dilihat pada tabel 3, 4 dan 5 .

Berdasar tabel 3, didapati tiga gaya kepemimpinan siginifikan mempengaruhi komitmen organisasi $(\mathrm{F}=96.827, \mathrm{p}<.05)$ dan produktivitas kerja $(\mathrm{F}=45.181, \mathrm{p}<.05)$. Oleh itu hipotesis pertama dapat diterima. Pada tabel 2 dan 3 didapatkan:

1. Kepemimpinan profetik dan kepemimpinan spiritual merupakan variabel independen yang dominan mempengaruhi komitmen organisasi $(\mathrm{F}=$ 145.909, $\mathrm{p}<.05$ dan $\mathrm{F}=282.037, \mathrm{p}<.05)$.

2. Dari tiga gaya kepemimpinan, hanya kepemimpinan spiritual dominan mempengaruhi produktivitas kerja $(\mathrm{F}=133,839, \mathrm{p}<.05)$.

Tabel 1. Pengaruh tiga gaya kepemimpinan terhadap komitmen organisasi dan produktivitas kerja (metode enter)

\begin{tabular}{lccc}
\hline \multicolumn{1}{c}{ Variabel } & $\mathrm{R}$ & $\mathrm{R} 2$ & $\mathrm{~F}$ \\
\hline komitmen organisasi & 0.760 & 0.578 & $96.827^{*}$ \\
produktivitas kerja & 0.625 & 0.390 & $45.181^{*}$
\end{tabular}

Tabel 2. Dominasi tiga gaya kepemimpinan terhadap komitmen organisasi

\begin{tabular}{lccc}
\hline Variabel Dominan & $\mathrm{r}$ & $\mathrm{R} 2$ & $\mathrm{~F}$ \\
\hline Kep. Spiritual & 0.754 & 0.569 & $282.037^{*}$ \\
Kep. Profetik & 0.760 & 0.578 & $145.909^{*}$ \\
\hline
\end{tabular}


97 I Jurnal Psikologi Talenta Vol. 4 No.1

Tabel 3. Dominasi tiga gaya kepemimpinan terhadap produktivitas kerja (metode stepwise)

\begin{tabular}{lccc}
\hline Variabel Dominan & $\mathrm{r}$ & $\mathrm{R} 2$ & $\mathrm{~F}$ \\
& & & \\
\hline Kep. Spiritual & 0.620 & 0.385 & $133.839^{*}$
\end{tabular}

Uji hipotesis kedua. Untuk menguji

dominasi tiga gaya kepemimpinnan dalam

tiga jenis organisasi yaitu bisnis, publik dan nonprofit dapat ditentukan dengan melihat tingginya nilai min (dengan ANOVA satu jalur). Hasil analisisnya dapaat dilihat dalam tabel 4. Berdasarkan tabel 4, maka dapat dinyatakan:

1. Keberadaan gaya kepemimpinan profetik lebih tinggi pada organisasi nonprofit $(\mathrm{F}=3.785, \mathrm{p}<.05)$ dibanding dengan jenis organisasi bisnis dan publik.

2. Keberadaan gaya kepemimpinan spiritual lebih tinggi pada organisasi nonprofit $(\mathrm{F}=4.920, \mathrm{p}<.05)$ dibanding dengan jenis organisasi bisnis dan publik.

3. Keberadaan gaya kepemimpinan transformasional lebih tinggi pada organisasi nonprofit $(\mathrm{F}=6.892, \mathrm{p}<.05)$ dibanding dengan jenis organisasi bisnis dan publik.

Berdasar temuan tersebut dapat disimpulkan bahwa keberadaan ketiga gaya kepemimpinan lebih tinggi pada organisasi nonprofit dibanding dengan jenis organisasi bisnis dan publik. Oleh itu hipotesis kedua dapat diterima.
Komitmen Organisasi dan Produktivitas Kerja

Tabel 4. Dominasi tiga gaya kepemimpinan dalam organisasi

\begin{tabular}{lrcc}
\hline \multicolumn{1}{c}{$\begin{array}{c}\text { Jenis } \\
\text { Organisasi }\end{array}$} & \multicolumn{3}{c}{ Gaya } \\
& Kepemimpinan \\
\cline { 2 - 4 } & Spiritual & Profetik & $\begin{array}{c}\text { Transfor- } \\
\text { masional }\end{array}$ \\
\hline Bisnis & 49.01 & 78.58 & 36.39 \\
Publik & 49.81 & 77.36 & 36.01 \\
Nonprofit & $\mathbf{5 2 . 1 3}$ & $\mathbf{8 2 . 0 6}$ & $\mathbf{3 8 . 9 9}$ \\
& F= 4.920* & F= 3.785* & F=6.892* \\
\hline
\end{tabular}

Berdasar hasil penelitian, tiga gaya kepemimpinan (profetik, spiritual dan transformasional) terbukti dapat mempengaruhi komitmen organisasi dan produktivitas kerja karyawan. Hasil ini sesuai dengan beberapa hasil kajian literatur sebelumnya. Hasil kajian di atas bermakna bahwa salah satu faktor yang dapat mempengaruhi komitmen organisasi dan produktivitas kerja anggota organisasi adalah pemimpin. Pernyataan itu sesuai dengan hasil penelitian yang dilakukan oleh Loke (2001) tentang pengaruh perilaku kepemimpinan terhadap kepuasan kerja, produktivitas dan komitmen organisasi. Hal itu didukung juga oleh pendapat Chairy (2002) yang menyatakan salah satu dimensi iklim psikologis yang secara konsisten berkorelasi positif dengan komitmen organisasi adalah kepimpinan.

Signifikannya kepemimpinan spiritual mempengaruhi komitmen organisasi dan produktivitas kerja sesuai dengan konsep dasar yang dikembangkan oleh Fry (2003 dan 2005) dan beberapa hasil penelitian lainnya. Hasil itu juga didukung oleh kajian konseptual yang dilakukan oleh Giacalone et al. (2005) yang menyatakan bahwa pengembangan kepimpinan spiritual di tempat kerja berpengaruh positif terhadap individu dan organisasi. Secara individu, anggota organisasi merasakan ketenangan, kebahagiaan, semangat, dan terwujudnya makna hidup dalam dirinya. Dari aspek 
organisasi dihasilkan pengaruh kepimpinan spiritual terhadap komitmen organisasi dan produktivitas kerja anggota organisasi. Selain itu, secara khsusus Pawar (2013) manyatakan dalam penelitiannya bahwa perilaku spiritual seorang pemimpin berpengaruh signifikan terhadap perilaku karyawan (bawahan) dalam organisasi.

Kemimpinan transformasional juga signifikan mempengaruhi komitmen organisasi dan produktivitas kerja. Hasil itu didukung oleh Zhu et al. (2005) dan Whittington et al. (2004) menyatakan bahwa kepimpinan transformasional mempunyai pengaruh terhadap outcomes pekerja dan organisasi. Sementara itu Ross dan Gray (2006) Purvanova et al. (2006) serta Spinelli (2006) menyatakan bahwa kepimpinan transformasional berperanan untuk meningkatkan komitmen organisasi dan produktivitas kerja anggota organisasi. Selain itu, hasil penelitian ini didukung oleh temuan Kieres (2012), menunjukkan perilaku kepemimpinan transformasional secara positif dapat mempengaruhi kepuasan kerja dan komitmen organisasi para guru.

Ditinjau dari kepemimpinan profetik, ada kemungkinan signifikannya kajian ini karena tempat pelaksaanaan kajian dilakukan dalam organisasi yang dikelola secara Islam atau berada pada lembaga syariah. Kemudian secara normatif, berdasarkan Arifiyanto dan Budiharto (2008) yang menyatakan adanya pengaruh kepimpinan nabi Muhammad SAW yang sangat besar bagi kehidupan organisasi umat Islam. Nilai-nilai kepimpinan nabi Muhammad SAW dapat berpengaruh terhadap terbentuknya jiwa pembaharu, etos kerja, dan kasih sayang serta kebermaknaan hidup seseorang serta terbangunnya budaya organisasi, komitmen organisasi dan produktivitas kerja. Hal tersebut sangat terkait dengan penelitian ini yang mengkaji dimensi keorganisasian dengan latarbelakang nilai moral, spiritual dan agama orang-orang di dalammya. Nilai spiritual dan agama tersebut membawa implikasi positif dalam kehidupan organisasi hingga ke masa depan. Itu didukung oleh hasil kajian konseptual Nurtjahjanti (2010) yang menegaskan bahwa spiritualitas dalam pekerjaan merupakan kemampuan menghadirkan keseluruhan diri karyawan untuk bekerja denggan nilai spiritual dan keyakinannya.

Hasil penelitian ini relevan dengan pernyataan Benefiel, et al. (2014). Ia menyatakan, penelitian tentang peran spiritualitas dan agama di tempat kerja (SRW) merupakan kajian ilmiah yang relatif baru, namun penerapannya mempunyai dampak signifikan terhadap individu dan dan hasil yang dicapai (outcomes) oleh organisasi. Kemudian Giacalone et al. (2005) menyatakan bahwa pengembangan kepemimpinan spiritual di tempat kerja berpengaruh positif terhadap individu dan organisasi. Secara individu, anggota organisasi merasakan ketenangan, kebahagiaan, semangat, dan terwujudnya makna hidup dalam dirinya. Dari aspek organisasi dihasilkan pengaruh terhadap komitmen organisasi dan produktivitas kerja. Selain itu, menurut Antonio (2007), menjelang akhir abad keduapuluh muncul kembali kegairahan spiritualitas di berbagai kalangan. Banyak pelaku bisnis telah mulai membawa agama atau spiritualitas ke wilayah bisnis. Di sudut lain, sebagian kalangan agamawan juga telah bergerak di bidang bisnis dengan membawa etika dan nilai-nilai keagamaan. Sedang Jesper Kunde dalam bukunya Corporate Religion (Antonio 2007) mengatakan bahwa di bidang manajemen terdapat semacam keperluan terhadap 
manajemen spiritual pada perusahaanperusahaan moderen. Kemudian menurut Fry (2003), sejak tahun 1980-an mulai terjadi pergeseran fokus dari teori kepemimpinan behavioral contingency (yang mempelajari perilaku pemimpin yang sesuai dengan situasi tertentu) menuju kepemimpinan strategik yang menekankan spiritual, visi, motivasi, dan pengendalian melalui nilai-nilai atau budaya di dalam kelompok yang adaptif terhadap perubahan lingkungan organisasi.

Hasil kedua dalam penelitian ini adalah keberadaan gaya kepemimpinan profetik, spiritual dan tranformasional lebih tinggi pada organisasi nonprofit dibanding dengan jenis organisasi bisnis dan publik. Hasil ini merupakan fenomena menarik, karena ketiga gaya kepemimpinan tersebut masing-masing memiliki karakteristik relatif berbeda. Walaupun ketiganya memiliki perbedaan karakter, namun keberadaannya lebih dominan pada organisasi nonprofit (sosial keagamaan). Konsep kepemimpinan profetik memiliki nilai tulus (ihklas) berbuat dan berkarya karena dilandasi motivasi ketuhanan (transenden ilahiyah). Kepemimpinan spiritual dapat mengembangkan karakter sosial. Hal itu didukung oleh pendapat Sweeney dan Fry (2012), yang menyatakan kepemimpinan spiritual memfasilitasi pengembangan kesadaran sosial, motivasi diri, nilai-nilai inti dan komponen identitas diri. Visi dan kesadaran sosial merupakan nilai-nilai keyakinan yang dapat mengembangkan kesadaran sosial dan keterampilan yang diperlukan untuk membangun hubungan yang positif.

Konsep dasar gaya kepemipinan profetik dan gaya kepemipinan spiritual diambil dari teologi dan moral agama. Namun dalam perkembangannya kedua gaya kepmimpinan itu memiliki perbedaan.
Konsep kepemimpinan spiritual dikembangkan oleh Fry sejak tahun 2003 tidak mengkaitkannya dengan masalah ketuhanan dan tidak menyinggung sisi keruhanian manusia. Ia mengarahkan dan mengaitkan spiritual itu pada masalah makna hidup, nilai-nilai dan keutuhan diri di tempat kerja. Seseorang dapat menemukan spiritualitas dari bekerja, belajar, berkarya, dan bahkan ketika menghadapi problematika dan penderitaan. Sedangkan kepemimpinan propetik bersumber dari sisi keruhanian manusia yang diperoleh dari pendekatan diri pada Allah SWT dan didapatkan dari mencontoh nilai keteladanan nabi Muhammad SAW. Hal itu sesuai dengan pendapat AlSarhi et al. (2014) bahwa kepemimpinan dalam Islam merupakan amanah, berdasar Kitab Suci Alquran dan Sunnah, (perkataan dan praktek dari Nabi Muhammad, saw) dan nilainya diartikulasikan dalam tauhid Ilahiyah (transenden).

Secara khusus, gaya kepemimpinan profetik merupakan gaya yang bersifat intrinsik berdasarkan syariah. Intrinsik syariah merupakan integrasi antara motivasi intrinsik individu dengan motivasi ilahiyah (trancenden), dimana keduanya berdimensi dunia (hasanah - happines) dan akhirat (salamah - salvation), sehingga hal itu memacu aktivitas kehidupan individu, kelompok dan organisasi cecara intrinsik. Nilai transenden dalm kepemimpinan profetik menurut Kontowijoyo (2006) terdapat dalam Al-Qur'an surat Ali Imron ayat 110: Катu adalah umat yang terbaik yang dilahirkan untuk manusia, menyuruh kepada yang ma'ruf, dan mencegah dari yang munkar, dan beriman kepada Allah. Sekiranya ahli kitab beriman, tentulah itu lebih baik bagi mereka, di antara mereka ada yang beriman, dan kebanyakan mereka adalah orang-orang yang fasik. (QS. Ali Imron : 
110). Ayat tersebut memiliki nilai kepemimpinan profetik, yaitu Ta'muruna bil ma'ruf (menyuruh kepada yang ma'ruf), bermakna misi humanisasi, yaitu memanusiakan manusia dan mengangkat harkat derajat hidup manusia. Tanhauna 'anil munkar (mencegah dari yang munkar) bermakna misi membebaskan, yaitu membebaskan manusia dari keterpurukan dan ketertindasan. Tu'minuna billah (mereka yang beriman) bermakna misi transendensi, yaitu manifestasi dari misi humanisasi dan liberalisasi yang diartikan sebagai kesadaran ilahiyah (ketuhanan).

Nilai-nilai tersebut sangat dibutuhkan organisasi dalam menata kehidupannya menghadapi perubahan lingkungan organisasi di era moderen. Selain bersifat transenden, kepemimpinan profetik model dari keteladanan Nabi Muhammad SAW. Keteladaan itu telah teruji dan terbukti, dimana dalam waktu 23 tahun nabi Muhammad SAW dapat mengadakan perubahan perilaku pada masyarakat jahiliyah Arab dan mengadakan perubahan peradaban ummat manusia yang berkemajuan. Ini didukung oleh Antino (2007) dalam bukunya Muhammad The Super Leader Super Manager yang mencoba melihat Rasulullah Muhammad SAW dengan kaca mata baru yang lebih luas yaitu bukan saja mengakui Rasulullah SAW sebagai nabi dan rasul tetapi juga menempatkannya sebagai pemilik traits of leadership dan models of management. Traits of Leadership Rasulullah SAW itu terdiri atas delapan bidang utama, yaitu: Self development atau personal leadership, bisnis dan kewirausahaan, kepemimpinan keluarga, dakwah, social (public) dan politik, pendidikan, sistem hukum, dan strategi militer. Oleh itu, figur Muhammad SAW menjadi pusat model kepemimpinan agama dan duniawi yang senantiasa relevan sepanjang zaman. Kesempurnaan gaya kepemimpinan profetik Nabi MuhammadSAW itu telah dijamin oleh Allah SWT dalam Al-Qur`an berikut: Sesungguhnya telah ada pada diri Rasulullah (Mumammad) itu suri teladan yang baik bagimu, (yaitu) bagi orang yang mengharap (rahmat) Allah dan (kedatangan) hari kiamat dan dia banyak menyebut Allah (QS.Al-Ahzab:21).

\section{KESIMPULAN}

Berdasarkan hasil penelitian dan pembahasan yang telah dipaparkan di hadapan, maka dapat diambil kesimpulan sebagai berikut:

1. Tiga gaya kepemimpinan memberi pengaruh signifikan terhadap komitmen organisasi dan produktivitas kerja. Dalam analisis dengan metode stepwise didapatkan gaya kepemimpinan yang dominan mempengaruhi variabel dependen. yaitu : a) kepemimpinan profetik dan spiritual dominan mempengaruhi komitmen organisasi. Produktivitas kerja dominan dipengaruhi oleh kepemimpinan spiritual.

2. Penelitian ini menemukan ketiga kepemimpinan (kepemimpinan spiritual, kepemimpinan profetik dan kepemimpinan transformasional) memiliki kesamaan keberadaan pada organisasi nonprofit.

\section{DAFTAR RUJUKAN}

Al-Qur`an dan terjemahannya.

Agustianto. (2008). Implementasi Ekonomi Syariah. Pascasarjana PSTTI Univ. Indonesia.

AlSarhi, Naji Zuhair., Salleh Lailawati M., Mohamed ZA., \& Amini, A.A. (2014). The West and Islam Perspective of Leadership International Affairs and Global 
Strategy. www.iiste.org ISSN 2224574X (Paper) ISSN 2224-8951 (Online) Vol.18.

Antonio, Muhammad Syafii. (2007). Muhammad SAW: The Super Leader Super Manager. Jakarta: ProLM Centre.

Arifiyanto, Denny \& Budiharto, Sus. (2008). Hubungan antara Kepemimpinan Profetik dengan Kepuasan Kerja. Kripsi Naskah Publikasi, Program Studi Psikologi Fakultas Psikologi dan Ilmu Sosial Budaya Universitas Islam Indonesia, Yogyakarta.

Bass, B. M. \& Avolio, B. J. (1992). Adapted with permission. MLQ forms can be obtained from Mind Garden, Inc., 1690 Woodside Rd., Suite 202, Redwood City, CA 94061, USA 650: 261-3500.

Benefiel, Margaret; Fry, Louis W.; Geigle, David. (2014). Spirituality and religion in the workplace: History, theory, and research. Psychology of Religion and Spirituality, Vol 6(3), Aug 2014, 175-187.

Budiharto, Sus. \& Himam, Fathul. (2006). Konstruk Teoritis dan Pengukuran Kepemimpinan Profetik. Jurnal Psikologi UGM. 33, 121-132.

Campbell, Robert A. (2008). Leadership succession in early Islam: exploring the nature and role of historical precedents. The Leadership Quarterly 19: 426-438.

Chairy, L. Seniati. (2002). Seputar komitmen organisasi. Makalah disampaikan dalam ccara silaturrahiem angkatan '86 Fakultas Psikologi UI Jakarta.

Chen, Chin-Yi \& Yang, Chin-Fang. (2012). The impact of spiritual leadership on organizational citizenship behavior: A multi-sample analysis. $J$ Bus Ethics, 105:107-114 DOI 10.1007/s10551011-0953-3.

Dewi. (2013). Pengaruh gaya kepemimpinan profetik dan transformasional terhadap produktivitas kerja; kajian pada karyawan PLTU Makassar. Skripsi, Fakultas Psikologi UNM, Makassar.

Fry, L. W. (2003). Toward a theory of spiritual leadership. The Leadership Quarterly, 14, 693-727.

Fry, L. W. (2005). Toward a theory of ethical and spiritual well-being, and corporate nonprofit responsibility through spiritual leadership. Forthcoming in Giacalone, R.A. and Jurkiewicz, C.L., Eds. Positive Psychology in Business Ethics and Corporate Responsibility pp. 47-83). Greenwich, CT: Information Age Publishing.

Fry, L. W. \& Matherly, J. L. (2006). Workplace Spirituality, Spiritual Leadership and Performance Excellence. Steven G. Rogelberg (Ed.), Encyclopedia of Industrial/Organizational Psychology. San Francisco: Sage Publications.

Fry, L. W. \& Slocum, John W. Jr. (2008). Maximizing the triple bottom line through spiritual leadership. Organizational Dynamics Vol. 37, No. 1: pp. 86-96.

Fry, L. W. \& Whittington, J. L. (2005). In search of Authenticity: Spiritual leadership theory as a source for future theory, research, and practice on authetic leadership, In W. Gardner, B. Avolio, \& F. Walumbwa (Eds.), Authentic leadership theory and practice: Origins, effects and development monographs in leadership and management, 3, 183200.

Fry, L.W. \& Whittington, J. L. (t.th.) Spiritual leadership theory as a paradigm for organization transformation and development. http://www. tarleton.edu/ fry/SLTOrg Devel.pdf Giacalone, R.A., Jurkiewicz, C.L., \& Fry, L.W. (2005). From advocacy to science: The next steps in workplace spirituality research. In R. Paloutzian 
\& C. Park, (Eds)., Handbook of the Psychology of Religion and Spirituality (pp. 515-528). Newbury Park, CA: Sage.

Haliding, Safri. (21 Januari 2011). Arah dan Proyeksi Ekonomi Islam. Harian Fajar, Makassar.

Hasan, Muhammad Tholhah. (2004). Islam dan masalah sumber daya manusia. Jakarta: Lantabora.

Howard R. Bromley \& Victoria A. Kirschner-Bromley. (2007). Are you a transformational leader? The Physicianexecutive.

Jandaghi, Gh. H., Matin Zarei, \& Farjami, A. (2008). Comparing Transformational Leadership in Successful and Unsuccessful Companies. Proceedings of World Cademy Of Science, Engineering And Technology, Volume 31 July 2008 Issn 1307-6884.

Luwu, Wija To. (Februari 2011). Ratulangi Pusat Bisnis Syariah Makassar. www.ekonomi.kompasiana.com,

Loke, J. Chiok Foong. (2001). Leadership behaviours: effects on job satisfaction, productivity and organizational commitment. Journal of Nursing Management; 9, 191-204.

Kieres, Katherine, H. (2012). A study of the value added by transformational leadership practices to teachers' job satisfaction and organizational commitment. Dissertation, Seton Hall University, UMI 3579651, Published by ProQuest LLC 2014.

Kuntowijoyo. (2006). Islam Sebagai Ilmu: Epistemologi, Metodologi, dan Etika. Yogyakarta: Tiara Wacana.

Khoshpanjeh, Mahsa, Afshin Rahnama, Mir Mohammad SeyyedKalan \& Ali Hoseinpour. (2012). Evaluating the Role of Spiritual Leadership Dimensions in Employee Empowerment and their Effect on Workforce Productivity. Journal of Basic and Applied Scientific Research, ISSN 2090-4304, 2(8)7681-7689
Malone, P. F. \& Fry, L. W. (2003). Transforming schools through spiritual leadership: A field experiment. Paper presented at the Academy of Management, Seattle, WA.

Mansyur, Ahmad Yasser (2013). Personal Prophetic Leadership Sebagai Model Pendidikan Karakter Intrinsik Atasi Korupsi. Jurnal Pendidikan Karakter. LPPMP UNY, Tahun III, Nomor 1, 15-27.

Mansyur, Ahmad Yasser. (2013). Psikologi Kepemimpinan: Pendekatan Intrinsik. Jakarta: Dapur Buku.

Matherly, L., Fry, L. \& Ouimet, J.R. (2005). Spiritual leadership and the strategic scorecard model of performance excellence: the case of Tomasso corporation. Paper presented at the August meeting of the Academy of Management, Honolulu, Hawaii.

Mowday, R.T., Porter, L.W., \& Steers, R.M. (1982). Employee-organization linkages: The psychology of commitment, absenteeism, and turnover. New York: Academic Press.

Nashir, Haedar. (2007). Meneguhkan ideologi gerakan Muhammadiyah. Malang: UPT Penerbitan Universitas Muhammadiyah Malang.

Nurtjahjanti, Harlina. (2010). Spiritualitas kerja sebagai ekspresi keinginan diri karyawan untuk mencari makna dan tujuan hidup dalam organisasi. Jurnal Psikologi Undip Vol. 7, No. 1, 20-30.

Pawar, Badrinarayan Shankar. (2014). Leadership spiritual behaviors toward subordinates: An empirical examination of the effects of a leader's individual spirituality and organizational spirituality. $J$ Bus Ethics 122:439-452 DOI 10.1007/s10551-013-1772-5.

Perbawa, Arip \& Sarasi, Vita. (2014). The effectiveness of human resources development based on prophetic leadership model in PPSDMS 
Nurulfikri Bandung, Indonesia. http://papers.ssrn.com/sol3/papers.cf m?abstract_id=2399658, Social Science Electronic Publishing, I, Date posted: February 23, 2014.

Purvanova, Radostina K., Bono, Joyce E. \& Dzieweczynski, Jessica. (2006). Transformational leadership, job characteristics, and organizational citizenship performance. Human Performance 19 (1): 1-22.

Rokhman, Wahibur. (2002). Upaya mencapai kesuksesan organisasi dalam menghadapi persainagn global. Usmara (editor). Paradigma Baru Manajemen Sumber Daya Manusia, hlm. 54-71. Yogyakarta: Amara Books.

Ross, John A. \& Gray, Peter. (2006). Transformational leadership and teacher commitment to organizational values: the mediating effects of collective teacher efficacy. School Effectiveness and School Improvement. Vol. 17, No. 2: pp. 179 $-199$.

Salusu J. (2000). Pengambilan keputusan stratejik untuk organisasi publik dan organisasi nonprofit. Jakarta: Gramedia.

Scott ， Kimberley G. (2008). Transcendental leadership: The impact of spirituality on the effectiveness of women small business owners. A Dissertation, Presented in Partial Fulfillment Of the Requirements for the Degree Doctor of Philosophy, Capella University.

Siagian, Sondang P. (2002). Kiat meningkatkan produktivitas kerja. Jakarta: Rineka Cipta.

Spinelli, Robert J. (2006). The applicability of Bass's model of transformational, transactional, and laissez-faire leadership in the hospital administrative environment. Heldref Publications.

Sweeney, Patrick J. \& Fry, Louis W. (2012). Character development through spiritual leadership. Consulting Psychology Journal: Practice and Research. American Psychological Association, Vol. 64, No. 2, 89-107 1065-9293/12/\$12.00 DOI: $10.1037 / \mathrm{a} 0028966$

Walsh, Michelle A. (2014). Prophetic pastoral care in the aftermath of trauma: forging a constructive practical theology of lived religion from organized trauma response ministries. Doctor of Philosophy Boston University School of Theology.

Zhu, W., Chew, Irene K.H., \& Spangler, William D. (2005). CEO transformational leadership and organizational outcomes: the mediating role of human-capitalenhancing human resource management. The Leadership Quarterly 16: 39-52. 